\title{
下北沢における景観体験・思いの意味に 関する研究一主体間の差異に着目して一
}

\author{
中内 和 1 ・山田 圭二郎 2 高橋 利之 3 ・川崎 雅史 4 \\ 1正会員＼cjkstart株式会社 三菱総合研究所（†100-8141 東京都千代田区永田町2-10-3） \\ E-mail:nanakauc@mri.co.jp \\ 2正会員 金沢工業大学 環境・建築学部（†921-8501 石川県野々市市扇が丘7-1） \\ E-mail: keijirou.yamada@neptune.kanazawa-it.ac.jp \\ 3正会員＼cjkstart株式会社オリエンタルコンサルタンツ（†151-0071 東京都渋谷区本町3-12-1） \\ E-mail: takahashi-ty@oriconsul.com \\ 4正会員 京都大学教授 大学院工学研究科（干 615-8540 京都府京都市西京区京都大学桂C1） \\ E-mail: Kawasaki.masashi.7s@kyoto-u.ac.jp
}

\begin{abstract}
現在各地では，行政主導で様々な景観形成計画が策定されており，これらは計画設計論への応用を見据 えた規制誘導のフィジカルな指針である．それにくわえ景観は，多様な主体の関わりや，それら主体によ るまちづくりへの意志と積極的な関与も必要である。 そのための試みの一つとして，人々が接する景観体 験・思いの意味を引き出して，差異や共通点が生じる背景を理解することや互いに共有できる接点を見出 すことが重要である.

本研究では下北沢を対象として，属性が異なる被験者で街歩き・WS を行い，景観体験・思いの意味を 解釈した．解釈した 17 の意味に関して，i）空間への接し方により発現する意味が異なること，ii）どの ような主体であれ，空間に参加する際には当事者性やその承認を通じて， ある種の帰属意識を求める視点 は共通していると考察された。
\end{abstract}

Key Words : meanings, thoughts of urban experience, actor, Shimokitazawa District

\section{1. はじめに}

\section{(1) 研究の背景 $\cdot$ 目的}

現在各地では，行政主導のさまざまな風景づくり計画 や景観形成計画が策定されている。世田谷区1)では,

「風景づくりの手引き」を策定して，世田谷らしい風景 づくりに取組んでいる。その手引きの中では，「地域の 個性を活かし，協働でまちの魅力を高める世田谷の風景 づくり」を理念に掲げ，主に建築物等の風景づくりの基 準の解説や，具体的な配慮の方法の例を示している. 他 にも，生駒市 ${ }^{2}$ では，「景観形成基本計画」を策定して， 生駒らしい景観を地勢，地域性，暮らしの視点から選び， 31のパターンを紹介している. これらの行政が展開して いる既存の景観計画は，地域の重要な景観資源と景観区 域を設定し，自然や街並夕との調和を目指す建築の形態 や色彩に関わる規制誘導のフィジカル（ハード）な指針 を与えており，その目的は，計画・設計論への応用を見 据えた「操作論的」な立場にある.
それにくわえ景観やまちづくりには，新たな住まい手 などを含めた多様な主体の関与が不可欠であり，それら 主体が，景観や“まち”を維持していくまちづくり（相 互理解の上で将来像を描き，実現するためのルールや方 法をつくること）への意志と積極的な活動や関与が必要 である。そのための試みの一つとして，地域に関わる 人々が接する景観体験から発される思いの意味を引き出 して，i）差異や共通点が生じる背景を理解すること， ii）どのような観点から捉えれば，主観の個別性（個々 人の体験や思い）を尊重しながら，互いに共有できる接 点が生まれるか考察することが重要であると考える. そ のような相互理解を促すための観点を見出すことが，今 後のまちづくりにおける共通認識を形成する際の, 出発 点や基盤になるのではないだろうか.

本研究では東京・下北沢を対象として，個人の主観に もとづく景観体験・思いの意味を引き出して，その差異 や共通点が生じる背景，およびそれらの個別性を越えた 相互理解を促すような接点の在り方を考察した. 


\section{(2) 研究の方法}

景観認識に関するデータ収集には，写真投影法とイン タビュー調査（図-1），主体単位のワークショップ（以 下WSとする）を組み合わせた（図-2）。得られた景観 認識に関するデータは，景観体験・思いを発した理由や きっかけにより意味を解釈した後，それらの意味を分類 して, 景観認識の構造を抽出した. 最後に, 解釈した 景観体験・思いの意味が，筆者の染意性が含まれていな いか個別インタビューにより確認した ${ }^{[1]}$ 。それぞれの詳 細な分析手法は各章で述べる.

また，多様な視点が得られるよう住民，商店街，下北 沢大学（下北沢に愛着がある方の団体），来街者の4主 体から各3名（計12名）を対象とした ${ }^{[2]}$.

\section{(3) 研究の位置付け}

写真投影法とインタビュー調査を組合せた研究には, 数多く蓄積があり，これら手法に新たな知見を加えるこ とに主眼を置いていない，例えば，松島ら゙は，里山地 域において，地域住民と移入住民間での水路に対する景 観認識や評価の違いを分析しており，景観を捉える側の 属性も含めて考察している，また，岡本ら ${ }^{4}$ は，WS（面 接調查）における写真投影法の可能性について，「写真 投影法は人が景観や環境をどのように認識しているかだ けでなく，人が環境をいかに意味づけるか，人と環境の 関わり方を伺い知ることができるＷWSで撮影写真を用 いることにより，意識や活動の実態，社会との関わりに 関する言語化が促進され，語りが誘引される．地域の中 での生活（活動）を撮影し，見返して，語る一連のプロ セスの中で，改めて自分の生活する地域と自分との結び つきや相互作用に気づくことは多い」と指摘している.

景観認識の意味に関して，K・Lynch「都市のイメー ジ」5)では，都市に対して人々が抱く共通のパブリック イメージを研究している. 環境イメージとしてidentity, structure, meaningを挙げ，「対象は実際的にしろ感情的 にしろ，観察者にとって何らかの“意味”を持たねばなら ない」と meaningの重要性を指摘しているが，「meaning のグループ・イメージは実体と関係の知覚ほどには一貫 しておらず複雑であり，個人的かつ主観的である」ため， 分析対象外としている. 景観認識を意味論的に迫った研 究には，萩下らのや山田らかの研究がある．萩下らは，被 験者の撮影写真と記述から，視覚像の景観認識の連関構

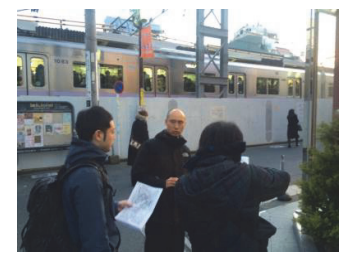

図-1 街歩き風景

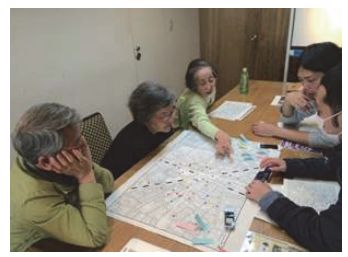

図-2 WS風景
造を抽出した．山田らは，哲学者・西研とともに「なつ かしさ」を手がかりとして，主観的な景観体験や感情の 個別性を越えて共有しうる普遍的な（人間的な）意味を， WSを通じて掘り下げており，その手法は本研究におい て重要な示唆を与えている.

これら既往研究をふまえ, 本研究では, 回答者の自由 な主観を拾い上げづらいアンケート調査やWSを主とす る経営やマネジメント手法ではなく, 現地体験インタビ ュー調査とWSを通じて，個人・主観的である景観の意 味を掘り下げる質的な分析を行ったことに新規性がある。

\section{2. 対象地概要}

\section{(1) 商店街の経緯・概要}

下北沢は東京・世田谷区に位置し，新宿や渋谷から電 車で10分の距離にある近隣型商店街である．駅を中心に 様相が異なる4商店街（しもきた商店街 : 来街者向けの 古着・雑貨が揃う，一番街 : 住民に日用品を供給, 南口 商店街 : 来街者向けの飲食店が揄う, 東会 : 本多劇場な ど文化施設や飲み屋が揃う8) で構成される（図-3）。

\section{（2）被験者の属性}

本研究の被験者として，下北沢に関わる主な4主体か ら選んだ。これら主体の特徴をまとめる。

\section{a) 住民（町内会）}

商店街周辺には住宅地が広がっているが，住民はスー パー以外に商店街を利用していない[3]. 自治組織は 12 町 内会があるが $[4]$ ，商店街周辺には高齢化が進む住宅街が あり，中心部には若年層が多く住む二極化傾向にある9. b) 商店街

商店街には，日用品を扱う店舗，来街者向けの洋服・ 雑貨，美容院等がある．休日にはこれら店舗を目的に多 くの来街者が訪れる都内有数の大規模な商店街である[ 1980年代頃に，建物がビル化を伴いながら旧住民世代が 賃貸業に転換したため, 現在はテナント店舗が多い[门。

\section{c) 下北沢大学}

しもきた商店街の副理事長を核に，下北沢で生まれ育 った人，学生時代に通っていた「しもきた好き」による 十数名の組織である. 商店街や周辺の街区を使ったイ心゙ ント等により，まちづくり・活性化に取組んでおり，住 民と商店街・来街者の「懸け橋」の役割を担う凸。

\section{d) 来街者}

来街者の多くは，電車で都内より訪れる若年層である. 下北沢では，2020年の東京オリンピック・パラリンピッ クを見据えて，外国人観光客の来街も見越した受け血整 備を進めている，その際に下北沢を歩き周る「体験」を どのようにPR寸るか重点的に検討している[8]. 


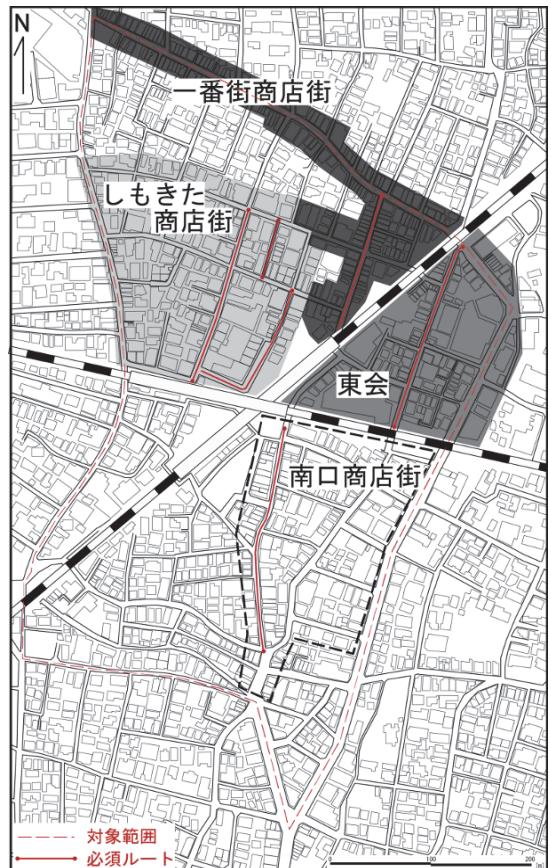

図-3 下北沢の地図と組織（対象範囲）

\section{（3）都市空間の変容を巡る経緯の整理}

対象地の都市再開発事業には，都市計画道路（補助 54 号線）や地区計画，小田急線地下化があり，これら によりヒューマンスケールな空間（路地や小規模建物） が失われることが㲘念される，そこで，WS や区民意見 の公募などにより，小田急線地下化後の空き地活用を住 民参加型で検討しているが，跡地利用が主な論点である. そのため, i）街全体を対象としていない，ii）ゾーニン グ検討に留まり商店街の具体的な空間整備まで議論され ていない，iii）行政が地域主導の提案を十分に汲み取り， 計画に反映できていないなど課題が見受けられる11).

\section{(4) 商店街の魅力と課題}

商店街形成の経緯から, 年齢層や目的が異なる人々が 利用している，ある店主は「若者，団塊の文化が重なり， 年代毎に行く場所が各々ある」と重層性を魅力と語って いる[9]．一方，i）住民が商店街を利用できない，ii）閉 鎖的（住民意見が汲み取られない），iii）若者向けの業 種が多く収益が少ない，iv）風俗店増加の課題がある ${ }^{[10]}$.

\section{3. 諸主体による場所・対象物の選好性}

\section{(1) 目的 - 分析方法}

街歩きおよびWSにより，場所・対象物の選好性を把 握した. まちづくりの現場では，意見集約や合意形成な どを目的としてWSを行うが，今回は立場が近い人達と の会話を通じて，体験・思いの内容を膨らませ，本人も 忘れていた内容を想起させることを目的として実施した.
表-1 対象者と調査実施日 ${ }^{[11]}$

\begin{tabular}{|c|c|c|}
\hline 年・性 & 居住 & 属性・特記事項 \\
\hline \multicolumn{3}{|c|}{ 住民（町内会）：2015/4/26(日) 11:00～13:45 } \\
\hline 60代女 & 在住 & 数十年前, 嫁いだことをきっかけに在住 \\
\hline 60代女 & 在住 & 数十年前, 嫁いだことをきつかけに在住 \\
\hline 60代男 & 在住 & 幼少期から今まで在住(不動産業) \\
\hline \multicolumn{3}{|c|}{ 商店街 : 2015/6/13(土)16:00〜17:30 } \\
\hline 40代男 & 在住 & 商店街副理事. 幼少期より在住(不動産業) \\
\hline 40代男 & 在住 & $\begin{array}{l}\text { 商店街理事. 幼少期より来街. 退職後は闇 } \\
\text { 市で魚屋を営む. 閉店後は不動産業に転換 }\end{array}$ \\
\hline 40代男 & 在住 & $\begin{array}{l}\text { 商店街理事. 幼少期より在住. 就職後は, } \\
\text { 近隣に転居. 3代目の店舗経営兼不動産業 }\end{array}$ \\
\hline \multicolumn{3}{|c|}{ 下北沢大学 : 2015/7/5(日) 11:30～12:15 } \\
\hline 30代男 & 地域外 & 大学まで在住. 5年前から参加(会社員) \\
\hline 30代女 & 在住 & 大学から在住. 3年前から参加(不動産業) \\
\hline 30代女 & 地域外 & 学生時代より来街. 5年前から参加(会社員) \\
\hline \multicolumn{3}{|c|}{ 来街者：2015/4/25(土) 16:00～21:15 } \\
\hline 20代男 & 地域外 & 今までにきたことはない(会社員) \\
\hline 201代男 & 地域外 & 今までにきたことはない(会社員) \\
\hline 20代男 & 地域外 & 今までにきたことはない(会社員) \\
\hline
\end{tabular}

被験者は各主体から3名ずつとして（表-1），図-3に 示寸範囲を歩いてもらった. 主観的な思いが発されるよ うi）好きな場所，ii）昔好きだった場所，iii）今残念な 場所という単純な聞き方で写真撮影してもらった。併せ て，それぞれに対して，選好性・理由及び体験内容をイ ンタビュー調査した．街歩き時の会話は，ICレコーダー で記録し，全文を文章で記録した，原則的に，自由に歩 いてもらったが，初めて訪れた来街者は，各商店街メイ ン通りを通るよう説明した ${ }^{[12]}$.WSでは，撮影写真を手 元に持ち，地図を指差しながら，自由に議論するものと した．撮影した全ての場所・対象物が議論に上らなくて もよいものとし，筆者達は議論が止まった際に発言を促 寸程度に留め, 基本的に, 対象者に議論の進行を委ねた。

\section{（2）諸主体による場所・対象物の選好性}

被験者により選好された全場所・対象物を, 主要な被 写体にまとめて, 主体ごとに分類した（表-2には，撮影 された全被写体を含んでいる）。さらに，主体ごとの撮 影場所を地図にプロットして, 諸主体による場所・対象 物の撮影場所を比較した（図-4）.

\section{a) 住民（町内会）}

住民では【日常生活で利用する（した）店舗】などが 選好され，これらがある一番街商店街や南口商店街で撮 影された（図-4）。他には，【閑静な住宅地】【緑】 【桜】といった生活空間を快適・豊かにする要素, 【劇 場】【有名人・役者】【観客】などサブカルチャー要素 に対しても好意的である. 一方, 残念なものとして,

【違法建築物】【廃墟】【喫煙所】【違法広告物】【放 置自転車】など都市の規律に反すると考えられるものが 指摘され，これらは住宅地で撮影された（図-4）。 


\section{b) 商店街}

商店街では町内会と同様，【日常生活で利用寸る（し た）店舗】【店舗の変遷・集積】などが選好された．対 象者は住民でもあり，【昔遊んだ境内・坂道】などの生 活場所や【緑・街路樹】【桜】など生活空間を快適・豊 かにする自然が選好されており，これらは住宅地で撮影 された（図-4）。一方，残念な場所は，【歓楽店】【喫 煙所】【客引き】など都市の風紀を乱すものであった. このように，商店街は住民と近い選好性だが，店舗の入 れ代わりや伐られた街路樹，喫煙所などを指摘しており 商店街を管理する立場として客観的に捉えている.

\section{c) 下北沢大学}

下北沢大学では，【サブカルチャーの店舗】【落書 き・壁面アート】【イベントポスター】【個性的な服装 の来街者】【コインランドリー】など様々な場所・対象 物が選好され，これらは住民や商店街とは異なる（図-
4）。ただし，他者と共有した活動の指摘はなく，外部 からの視点である。一方，残念な場所は，選好対象 （【小規模な店舗】など）が失われるほか，【ゴミ置き 場】【放置自転車】など都市の清潔感やマナ一に関する 指摘をしており，これらは住民や商店街と共通している. d) 来街者

来街者では，【店舗】【住宅】【自然】【人など下 北沢大学と同様に様々な場所・対象物が選好され，あら ゆる場所で撮影された（図-4）。他にも【路地】【溢れ 出し】【ポケットパーク】など “珍しいもの”が選好さ れた。 これらは雑誌記事の “らしさ”の描写と近く, 来 街者の選好性にメディア・イメージは何らか影響を与え ていると想定される ${ }^{[13]}$. 一方，来街者にとっては生活空 間ではないため，生活に由来する対象を選好していない， また，上述の“珍しさ”を認識しづらい一番街商店街を 全く撮影しておらず，これは住民や商店街とは異なる.

表-2 諸主体が撮影した場所・対象物（項目別）

\begin{tabular}{|c|c|c|c|c|}
\hline 項目 & 住民 & 商店街 & 下北沢大学 & 来街者 \\
\hline \multicolumn{5}{|c|}{ 今好きな場所 } \\
\hline 店舗 & $\begin{array}{l}\text { 店舗(よく利用/生活に利用/ } \\
\text { 話題がある), 店構え }\end{array}$ & $\begin{array}{l}\text { 店舗(よく利用噺しくできた/お } \\
\text { しゃれな/仰象深い), 店舗の看 } \\
\text { 板, 小規模な店舗・その集積 }\end{array}$ & $\begin{array}{l}\text { 店舗(生活に利用噡題性/新しい/お } \\
\text { しゃれ印象深い/チェーン), 闇 } \\
\text { 市, 小規模店舗, 雑居ビル, ライ } \\
\text { ブハウス, 劇場 }\end{array}$ & $\begin{array}{l}\text { 店舗(印象深い/新しくできた/おし } \\
\text { やれ), 闇市, 小規模な店舗, 店 } \\
\text { 構え }\end{array}$ \\
\hline 建物 & - & 学生アパート, 建物の並び & コインランドリー & 建物のファサード \\
\hline 住宅 & 住宅地 & 住宅の庭, 古民家, 壁 & 住宅地 & 住宅地, 民家 \\
\hline 街路 & 通り, 路地 & 通り, 路地 & 通り, 路地 & 通り, 路地, 三叉路, 起伏 \\
\hline 空間 & - & $\begin{array}{l}\text { ポケットパーク, 寺院, 境内, } \\
\text { 空き地, 車庫・倉庫, 空, 遠景 } \\
\text { に見えるビル群 }\end{array}$ & ポケットパーク, 踏切 & $\begin{array}{l}\text { ポケットパーク, 神社, 突込空 } \\
\text { 間, 喫煙所, ホーム, 線路, 駐車 } \\
\text { 場, 踏切, 空 }\end{array}$ \\
\hline 自然 & 緑, 桜 & 緑, 桜, 街路樹, 鉢植 & 緑 & 緑, 街路樹, 鉢植, 庭木 \\
\hline 要素 & 落書き, あふれ出し & 地蔵, あふれ出し, 風 & $\begin{array}{l}\text { 落書き, 壁面アート, イベントポ } \\
\text { スター, あふれ出し }\end{array}$ & $\begin{array}{l}\text { 落書き, 溢れ出し, ポスター, 看 } \\
\text { 板, 広告物, 放置自転車, 表札 }\end{array}$ \\
\hline 人 & - & 馴染みのある店主 & $\begin{array}{l}\text { 生活感あふれる来街者, 店主, 若 } \\
\text { 者, 役者, 観客 }\end{array}$ & $\begin{array}{l}\text { おしやれな来街者, 来街者の多 } \\
\text { さ, 店先にたむうう人 }\end{array}$ \\
\hline \multicolumn{5}{|c|}{ 昔好きだった場所 } \\
\hline 店舗 & $\begin{array}{l}\text { 店舗(よく利用/生活利用), } \\
\text { 映画館, 劇場, 銭湯, }\end{array}$ & $\begin{array}{l}\text { 店舗(生活利用/仰象深い), 映画 } \\
\text { 館, 屋上遊園地, 歓楽店, 銭湯 }\end{array}$ & $\begin{array}{l}\text { 店舗(よく利用仰象深い), サブカ } \\
\text { ルチャーの店舗, 闇市 }\end{array}$ & \\
\hline 建物 & 建物，空き家 & メンマ工場 & - & \\
\hline 街路 & 通り & 通り, 電柱 & - & \\
\hline 空間 & 境内, 土手, 線路, & 踏切 & 駅前にあった噴水，土手 & \\
\hline 自然 & 緑, 桜の木, 富士山 & - & - & \\
\hline 要素 & あふれ出し & あふれ出し, 工場の臭い & 駅ホームの柵, 落書き & \\
\hline 人 & $\begin{array}{l}\text { 有名人・役者, 店主, 住 } \\
\text { 民, 来街者, 観客 }\end{array}$ & $\begin{array}{l}\text { キャバレー, 踏切をくぐる学 } \\
\text { 生, 昔の遊び仲間達 }\end{array}$ & - & \\
\hline \multicolumn{5}{|c|}{ 今残念な場所 } \\
\hline 店舗 & $\begin{array}{l}\text { 占舗(よく利用/チェーン } \\
\text { 店), 店先, } \\
\end{array}$ & 店舗(チェーン店), 歓楽店 & $\begin{array}{l}\text { 店舗(話題性仰象深い/チェーン), } \\
\text { 小規模店舗 }\end{array}$ & 店舗(新しい/おしやれ/チェーン) \\
\hline 建物 & $\begin{array}{l}\text { 建物, 違法建築物, 取り壊 } \\
\text { しが決定した廃墟 }\end{array}$ & - & 巨大な商業施設 & $\begin{array}{l}\text { 巨大商業施設, 建物, 建物の壁 } \\
\text { 面, 塀, 古い建物 }\end{array}$ \\
\hline 住宅 & - & - & - & 住宅地 \\
\hline 街路 & $\begin{array}{l}\text { 通り, 路地, 段差, 舗装, } \\
\text { 電柱, 角地の隅切 }\end{array}$ & 伐られた街路樹 & - & 通り, 路地 \\
\hline 空間 & 駐車場, 空地, 喫煙所 & 喫煙所 & 駅南口の改札前, 踏切 & 駐車場, 倉庫 \\
\hline 要素 & $\begin{array}{l}\text { あふれ出し, 広告・落書 } \\
\text { き, 花壇, 放置自転車, 客 } \\
\text { 引き, 通りの騒音 } \\
\end{array}$ & あふれ出し, 線路, 放置自転車 & $\begin{array}{l}\text { ゴミ置き場, 駅前に停車するタク } \\
\text { シー, 落書き, 放置自転車, あふ } \\
\text { れ出し }\end{array}$ & $\begin{array}{l}\text { あふれ出し, ポスター, 商店街の } \\
\text { ゲート, 落書き, 放置自転車 }\end{array}$ \\
\hline 人 & 店先にたむろう人 & 客引き & 駅前でたむろする学生達 & - \\
\hline
\end{tabular}




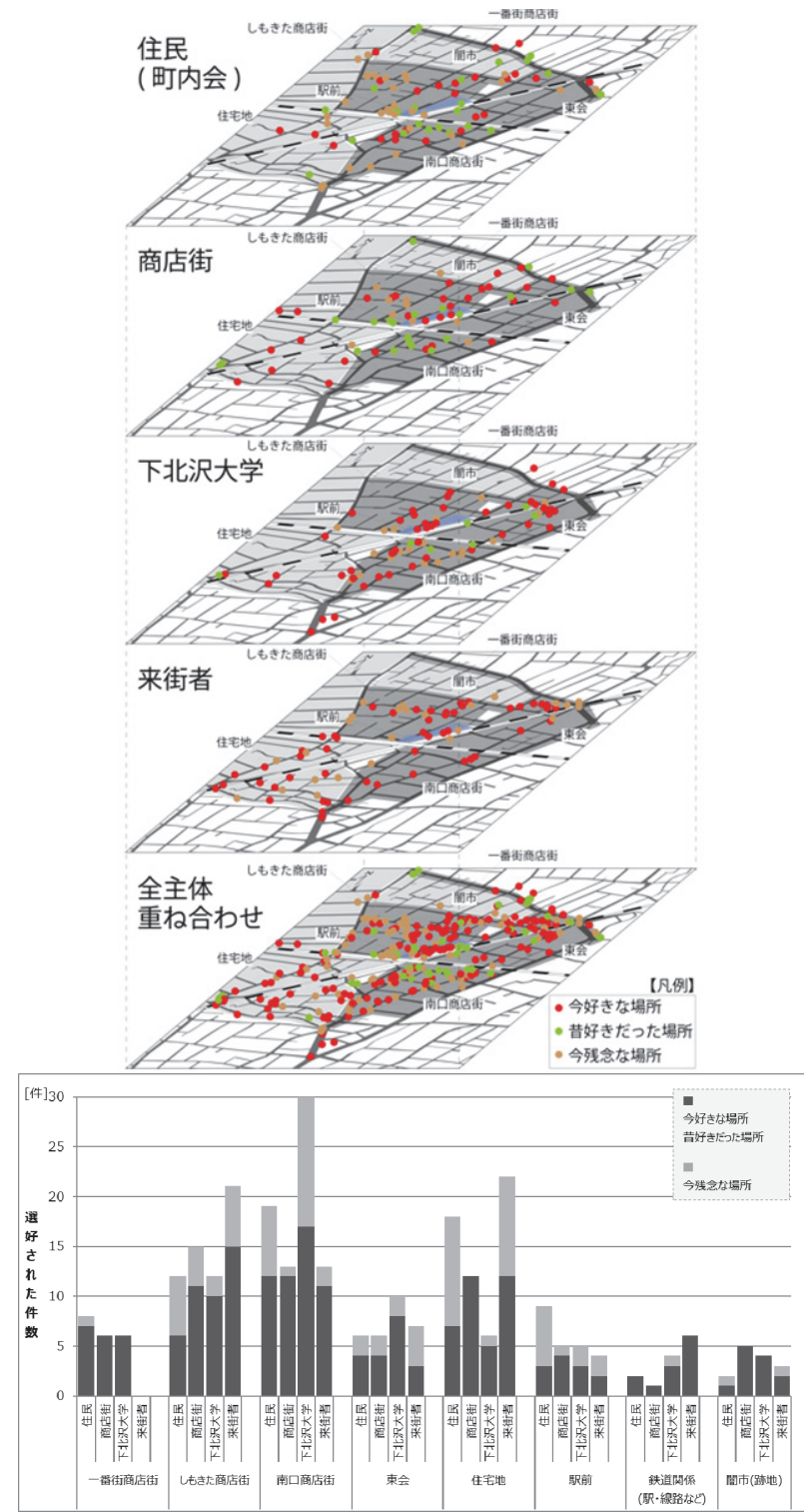

図-4 選好された場所・対象物の分布（主体単位）

\section{（3）諸主体による下北沢らしさの捉え方}

個人・主体が認識する地域らしさ（地域に共有される アイデンティティ）を把握するため，WSでは直接的に “下北沢らしさ”を議論してもらった（表-3）。

地域と日常的に関わりがある住民と商店街は，「賑や かさと静けさが相まり，住んでいる場所により印象が異 なる」（住民），「雑多で何でも許寸雾囲気. 個々で商 売を成立たせながらも，街全体で受け止めている」（商 店街）など空間の対比や雑多性，およびそれを受け入れ る街の様子に“下北沢らしさ”を捉えている.

一方，外部の視点である下北沢大学は，「個性的な店 主が店や街の雾囲気に影響している」など個性的な雾囲 気が漂う街の様子に“下北沢らしさ”を捉えており，来 街者は「杂倠誌でタた塀にかけられた古着」など事前のイ メージと一致するかで判断している. 来街者以外は “下 北沢らしさ”を街の雰囲気に捉えているが，来街者は具 体的な対象を指摘している点も特徵的である.
表-3 その他の「下北沢らしさ」の議論内容

\begin{tabular}{|c|c|}
\hline & 「下北沢らしさ」の議論（本文以外） \\
\hline 住民 & $\begin{array}{l}\cdot \text { ・゙゙ちゃごちやしていて, それが許されるところ } \\
\cdot \text { ・とにかく路地が多く，訳が分からない街という印象 }\end{array}$ \\
\hline 商店街 & $\begin{array}{l}\text { ·色んな人が関わり若者から年配も受入れるし, 文化 } \\
\text { 的でもある，伸び白が大きく色んなものを受入れる } \\
\text { ・マンガを読む人，短パンの人，柴犬を連れた文豪・ } \\
\text { 有名人も歩いており，色んなものがあり混沌 }\end{array}$ \\
\hline $\begin{array}{l}\text { 下北沢 } \\
\text { 大学 }\end{array}$ & $\begin{array}{l}\text { ・闇市の立ち飲み屋, 誰が買っているか分からない古 } \\
\text { 着屋などの個人経営店 } \\
\text { ・人ごみの通りという風景. 歩いている人からアウェ } \\
\text { イ感を感じるが, サブカル臭を感じる }\end{array}$ \\
\hline 来街者 & $\begin{array}{l}\text { ・私道に看板をはみ出している. 店舗間口に対して平 } \\
\text { 行でなく垂直に置いており，危険ながらもらしい } \\
\text { •店主に声を掛けずに外のテラスに客が腰を下ろす姿 }\end{array}$ \\
\hline
\end{tabular}

\section{(4) まとめ}

街歩きとWSを通じて，場所・対象物の選好性や，個 人・主体が認識する地域らしさが共有されうる観点とな るか確認した．住民と商店街は，“まち”という空間を 日常接する場として捉え，生活空間を快適・豊かにする 対象が選好されたが，下北沢大学と来街者は，外部の視 点から街の変化や “下北沢らしさ”を捉え, 様々な対象 が選好された．そのため，このような空間構成要素や地 域資源という個別要素の観点は, 被験者や主体の属性 背景に影響されるため, 共有されづらいと示唆された.

\section{4. 景観体験・思いの意味の解釈および景観認識 の構造の抽出}

\section{(1) 概要 $\cdot$ 分析方法}

WSで相互に話し合う中で，景観体験・思いの意味を 深く掘り下げてもらい，個人や主体間を越えて共感され うる意味が発現されるか確認した。 その取り出し方は, まず被験者の発話内容の中で，その意味を発した理由・ きっかけを発見論的にグルーピングして解釈した（景観 体験・思いの意味）。さらに，解釈した景観体験・思い の意味を分類して, 景観認識の構造を抽出した.

\section{（2）景観体験・思いの意味の解䣋}

得られた景観認識に関するデータは4主体計288の発言 であり, 紙面の都合上，全ての発言は掲載できないが, 4章末尾（表-4〜7）にできる限り掲載した（景観体験・ 思いの意味と景観認識の構造を一体的に示した）。

これら発言内容が発された理由・きっかけにより, 17 の景観体験・思いの意味に解釈した. 本節では, 解釈し た景観体験・思いの意味の定義と具体例を述べる．また， 複数の意味を含む発言・コメントは, 該当する複数の意 味双方に分類した. 


\section{i. 空間の非日常性}

日常からかけ離れていることや，街並夕と調和せず珍 しいと感じる佇まい，具体例には，【テレビで紹介され 人が集まる珍しい様子】【住宅地にある珍しい地蔵】な ど，普段は見慣れない様子や状態から認識された。

ii. 洗練されていないさま[14]

視対象から洗練されていない気安さを感じられ，誰で も気軽に選択・参加できる佇まい，具体例には，【生 活感があふれる服装で我が街みたいに歩く若者】【物好 きが描く落書き】のように，生活感が感じられる様子や 完成されていない様子から認識された。

iii. 公的社交・私的交歓 ${ }^{[15]}$

人々が交流などを楽しみ，さんざめきを感じる佇まい 具体例には，【劇場前では役者と観客が集い賑わう】

【闇市跡は広場として様々な活動・イベントに利用され る】など，人々の交流する様子や活動など，対象地の 人・コミュニティが放つ賑わいから認識された。

iv. 空間の広がり [16]

あるきっかけにより「私」がいる空間や，「私」と視 対象の間に一定の広がりを感じる佇まい. 具体例には,

【ポケットパークは，住宅地が静かだと素通りするが, 一帯が賑わってると気付く】など，商店街の喧騒をきっ かけとして，対比的に「私」がいる空間が認識された. v. 奥への誘い[17]

視対象により，特定の領域に入り込んだような奥性を 感じ，期待感や好奇心を掻き立てられる佇まい，具体例 には，【三叉路はそれぞれ行先や起伏が異なり，それぞ れの道がどこに繋がるんだろう】など, 路地, 微地形, 密集する建物など対象地の空間の多様さから認識された。 vi. 安全な棲息空間

「私」がいる空間に対して，手入れされているなど安 心感や安全性を感じられる佇まい，具体例には，【車が あまり通らない細い道は安心して歩ける】など，車通り や声掛けなどがなく安心して歩ける通りなど認識された。 vii. 自然の気配 ${ }^{[18]}$

「私」を超越する他者(季節の移ろい，自然など)が体 感される佇まい. 具体例には，【街路上のプランターも 緑の連続性を演出】【ポケットパークは空が抜けていて 開放的】など，街に点在するプランター，坦間見える空 や，通り抜ける風といった要素から認識された.

viii. 時の気配・新陳代謝 ${ }^{[19]}$

視対象から時間の流れや変化を予感・体感できる佇ま い. 具体例には，【昭和の名残を残す闇市】など，時間 の経過やその蓄積を感じられる闇市などから認識された. ix. 親和的な空間

視対象から自身の活動などを連想して密接さ感じる佇 まい，具体例には，【学生時代，行ったり来たりした通 り】など慣れ親しんだ場所，【踏み切りを潜る学生を見
て，かつての自分を思い出す】など，自身を投影する対 象を通じて間接的に自身の活動を連想するものもあつた. X. 活動の営みの痕跡[20]

視対象から他者の活動を連想する佇まい，具体例には， 【イベントポスターは，人々が街を楽しむ活気や活動を 感じる】【庭の緑を手入れしていると感じる】など，イ ベント活動, 手入れをする活動などが想起された.

xi. 共同的な活動

視対象から「私」と「他者」が共有した活動や時間が 連想される佇まい，具体例には，【小学生の頃，兄と祖 母と鑑賞した映画館】など，家族や住民同士といった他 人達との思い出や活動が想起された.

xii. 共同体の拠点 ${ }^{[21]}$

「私」と「他者達」の活動（xi. 共同的な活動）の拠 点となる場所・佇まい. 具体例には，【昔あった市場は 景品が面白く友達が集まる場所】など，住民達が多く集 う飲食店や市場などにおいて認識された。

xiii. まちの縁側[22]

視対象から連想される他者の活動が，「私」の空間・ 意識を越えて，公共的なコミュニティに働きかけている と連想される佇まい，具体例には，【道に並べられた看 板は，公共空間の使い方が独特. 看板が規制に捉われず あふれ出してる】ように，道に並べられた看板は，街や 通行客に働きかけていることが連想された。

xiv. 自然発生的な規範意識

視対象から連想される他者の活動の背景にある, 社会 的ルールや他者への配慮が感じられる佇まい. 具体例に は，【店頭の喫煙スペースは，灰が舞うため住民は良く 思っていない】など，住民への配慮について指摘された. $\mathrm{xv}$. 主体的な意志

視対象から連想される他者の活動に対して，主体的な 意思や個性が感じられる佇まい，具体例には，【店主の 遊び心がディスプレイにも表れている】など，店主の意 思や個性が表出するディスプレイなどにより連想された. xvi. 私の自由な選択

視対象や場所へ「私」が参加する際に，個人の裁量で 自由に選択できる佇まい. 具体例には，【イベントポス ターは地元の人が盛り上げようとやっていて，面白いこ とやっているからおいでよという感じ】など，視対象を 通じて連想される他者の活動などに対して, 自由に参 加・選択できる様子が指摘された.

xvii. 当事者性の承認

視対象から他者の活動が連想され，その背景にある他 者との承認・協調関係が感じられる佇まい. 具体例には, 【所有者の許可を得てデザインされた駐車場の落書き】 は大家が許可して表象する景観であり，【おしゃれな服 装の若者達を受入れて，育てている街の雰囲気】は，街 が個性的な若者達を受け入れている様子が指摘された. 


\section{（3）景観認識の構造の抽出}

解釈した17の景観体験・思いの意味を分類して, 景観 認識の構造を抽出をした。その結果，a）視対象の表層 (印象評価型），b）空間・状態（知覚認識型），c）連 想される人の活動（意味付与型），d）c）の背景にある 意識や作法（メタ意味型）に分類された（図-5）.

\section{a) 印象評価型}

i. 空間の非日常性，ii. 洗礼されていないさま，iii. 公的 社交・私的交歓は，視対象そのものに捉える印象評価の 類型であり，「記号論」にあてはめて解釈できる．記号 論は，建築要素や街並みの構造解釈に用いられ，池上は

「知覚される色，素材，テクスチャ，形状等は記号表現 として発信され，受信者は記号表現を記号内容として受 信して，イメージを形成する」と述心゙13)，知覚認識でき る形や色彩の見え方・表層による議論である.

\section{b) 知覚認識型}

iv. 空間の広がり，v. 奥への誘い，vi.安全な棲息空間， vii. 自然の気配，viii. 時の気配・新陳代謝は，視対象を通 じて，「私」がいる空間や気配が知覚認識される類型で あり，「景域論・空間認知」にあてはめて解釈できる. 景域論・空間認知では, Cullenは期待感を自分の周囲の 「こちら」の空間とその先の「あちら」の空間との関係 性を示すhere and thereの概念と結びつけ，隠された空間 領域として意味づけている ${ }^{14}$. 松本は，期待感の意味と して, 不可視空間への意識や空間の連続性, リズム感が ある，遠近感・囲まれ感などを指摘する ${ }^{15}$.

c) 意味付与型

ix. 親和的な空間， $\mathrm{x}$. 共同的な活動，xi. 活動の営みの痕 跡, xii. 共同体の拠点, xiii. まちの縁側は, 視対象を通じ て人の活動を連想する類型であり，「仮想行動理論」に あてはめて解釈できる．仮想行動理論は，ギブソンが述 べた「アフォーダンス」を中村が発展させ「人は身の回 りの環境を眺めると同時に，そこでどのような行動が可 能かを瞬時に知覚し，自身の仮想体験を予測評価できる. 景観を写真としてではなく, 想像し, 中に入り込んで,
そこで何ができるか，何をしたいかを考え，その景観に 対する評価の一因とする」と指摘する ${ }^{10}$.

\section{d) メ夕意味型}

xiv. 自然発生的な規範意識, $x v$. 主体的な意志, xvi. 私 の自由な選択, xvii. 当事者性の承認は, 視対象により連 想された人の活動の背景にある意識や作法などのメタな レベルの意味を読取る類型であり，仮想行動理論の活動 の背景まで掘下げていると解釈できる．このメタなレべ ルの視点は，私がその空間にどのような意味を持たせる かを越えて，“まち”という様々な個人や主体の関与や 思惑が作用する “地域社会（コミュニティ）”において, 個人が地域社会に参加する上での「作法」や「（参加し ている，承認されている）感覚」を表しているといえる.

\section{（4）諸主体が捉える景観体験・思いの意味の考察}

解釈した景観体験・思いの意味が，主体間で共通して 発現しているか確認した（表-8）。解勫した17の意味に 関して，空間の直接的な意味を表す3類型（a）印象評価 型，b）知覚認識型，c）意味付与型）では，x. 共同的な 活動，xii. 共同体の拠点は空間に日常接する主体（住民, 商店街）で発現され，ii. 洗練されていないさま，xiii. ま ちの縁側は外部として空間に接する主体（下北沢大学， 来街者）で発現された。このように空間への接し方（属 性）により，発現される意味が異なることが確認された。 最後に, メ夕意味型の $4 つ の$ 意味は, 商店街のxvi. 私の 自由な選択を除き，各主体において全て発現された。 メ 夕意味型は，前述した通り，私が空間に持たせる意味を 越え，地域に関わる主体がどのようにその場所に関わろ うとする，あるいは関わりたいと願うかという（潜在的 な）意志の表れと解釈できる，つまり，どのような主体 であれ，当事者性（xv. 主体的な意志，xvi. 私の自由な選 択）とその承認（xiv. 当事者性の承認（許されている, 受け止められている感覚））を通じて，場所・地域社会 への「帰属の感覚」を求めている視点は共通していると 考察できる. 一方， メ夕意味型に分類される景観体験・

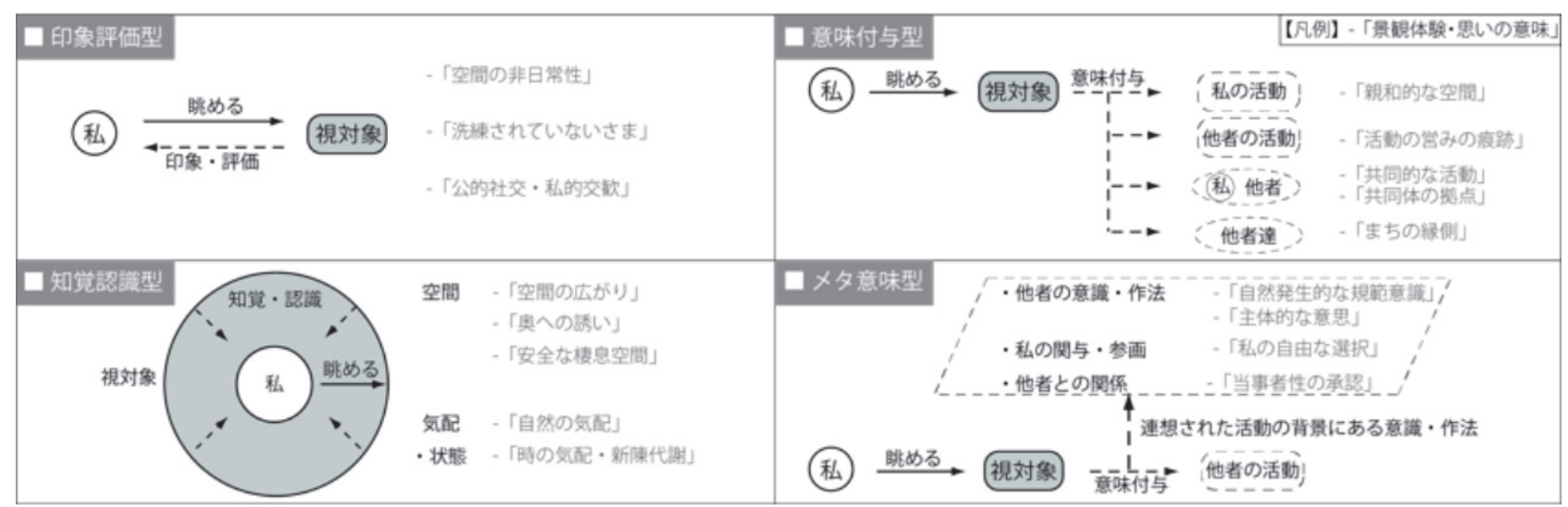

図-5＼cjkstart景観認識の構造（4類型，17の意味） 
表-4 景観体験・思いの意味（a）印象評価型）

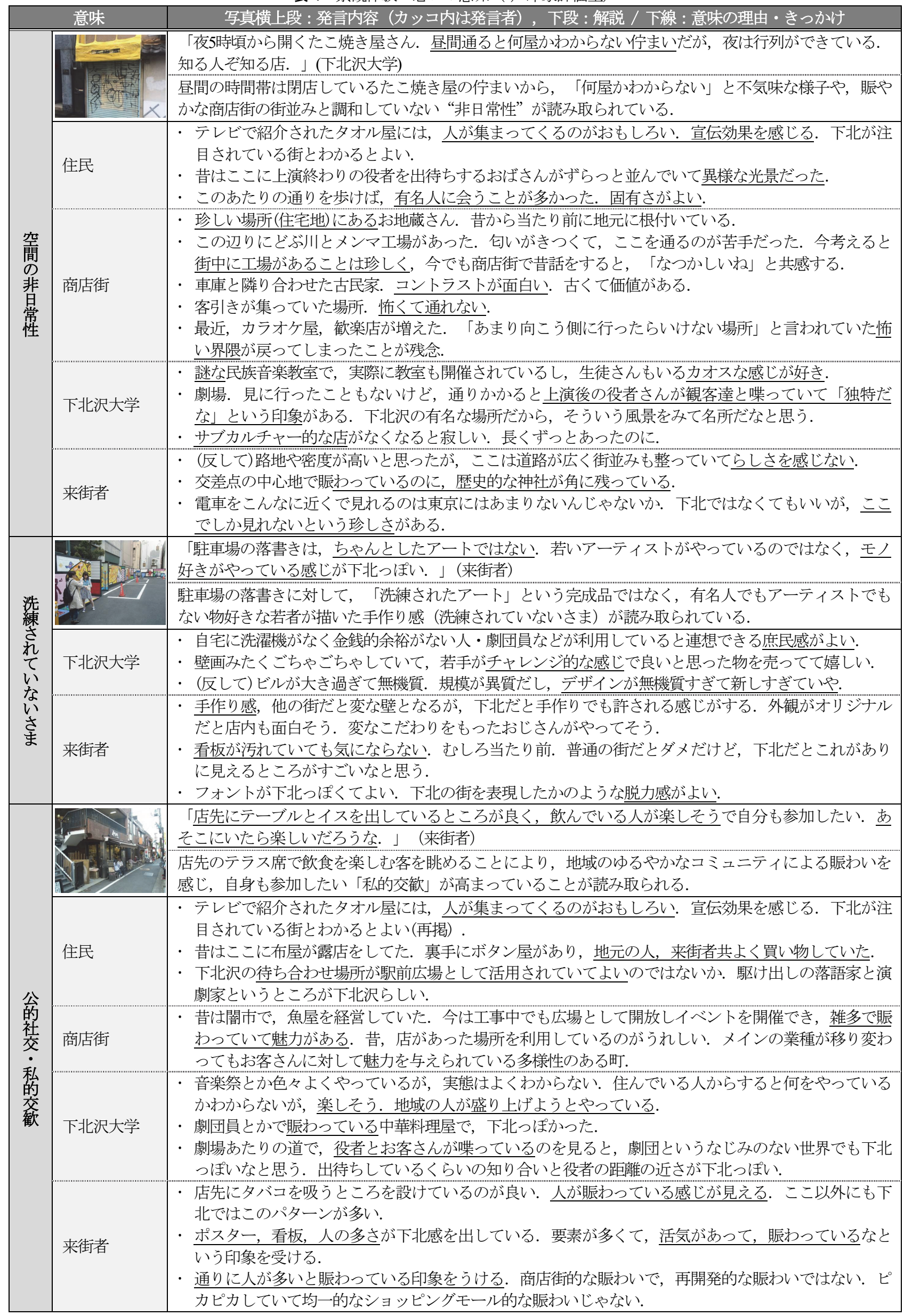


表-5 景観体験・思いの意味（b）知覚認識型）

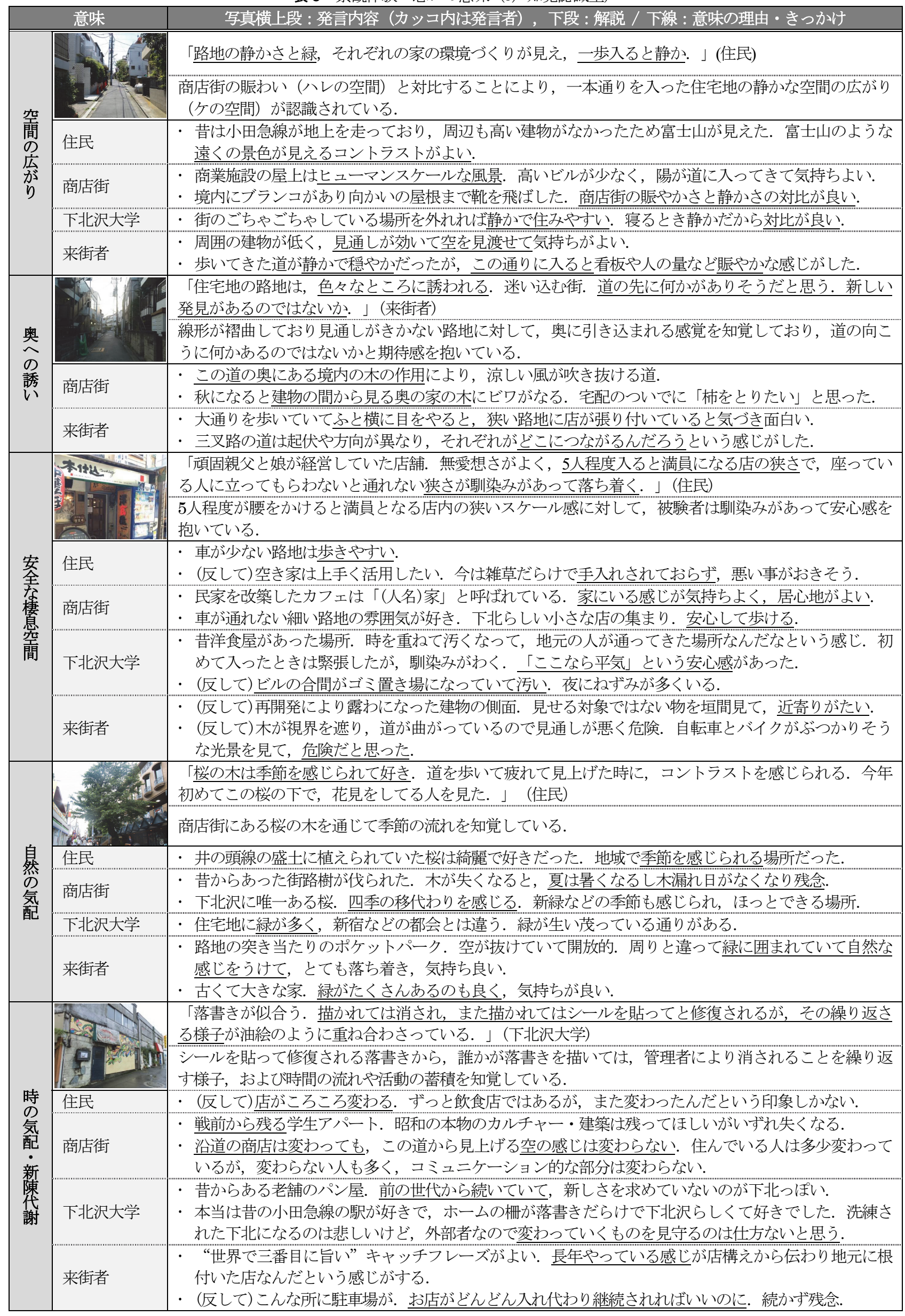


表-6 景観体験・思いの意味（c）意味付与型）

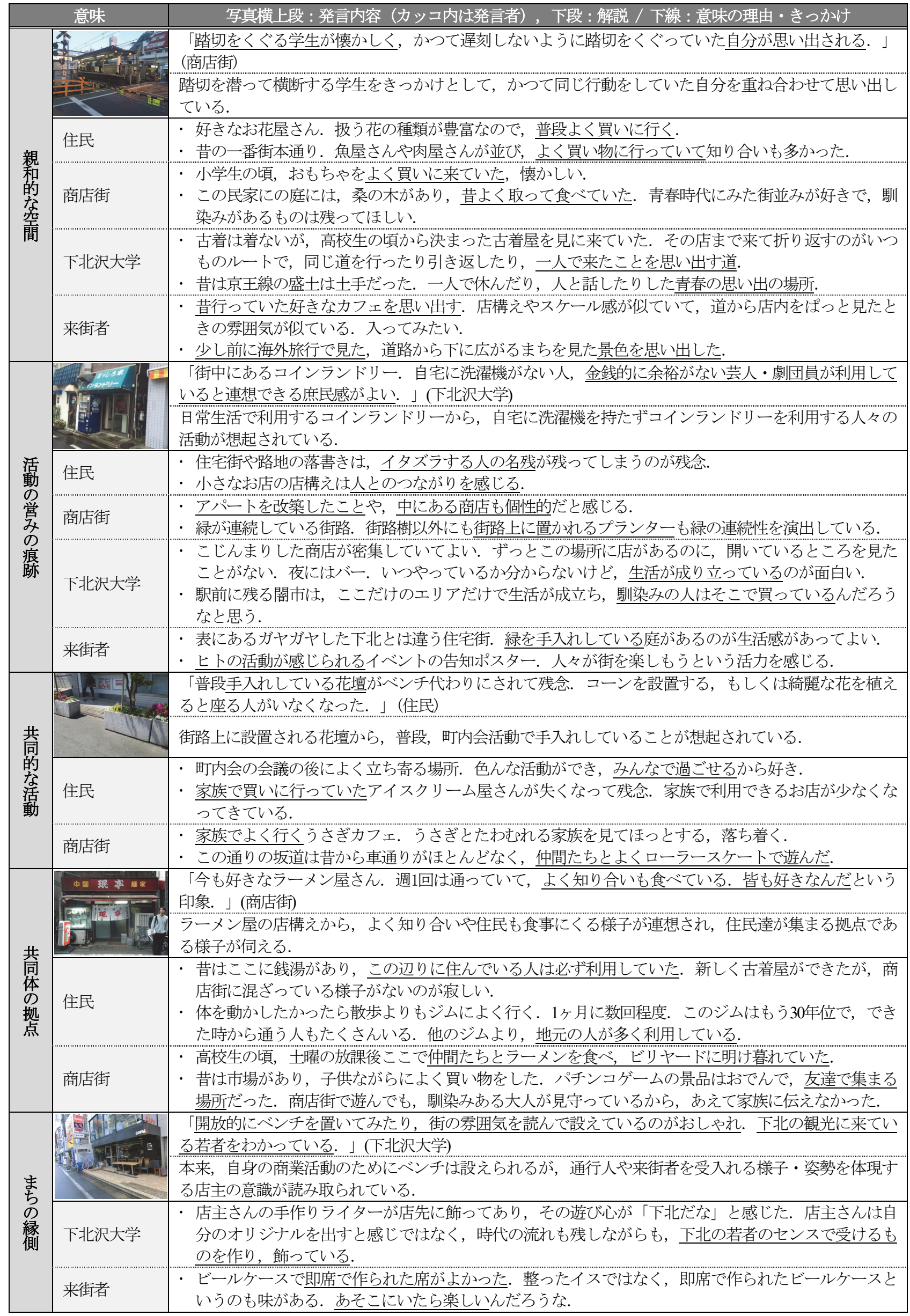


表-7 景観体験・思いの意味（d）メ夕意味型）

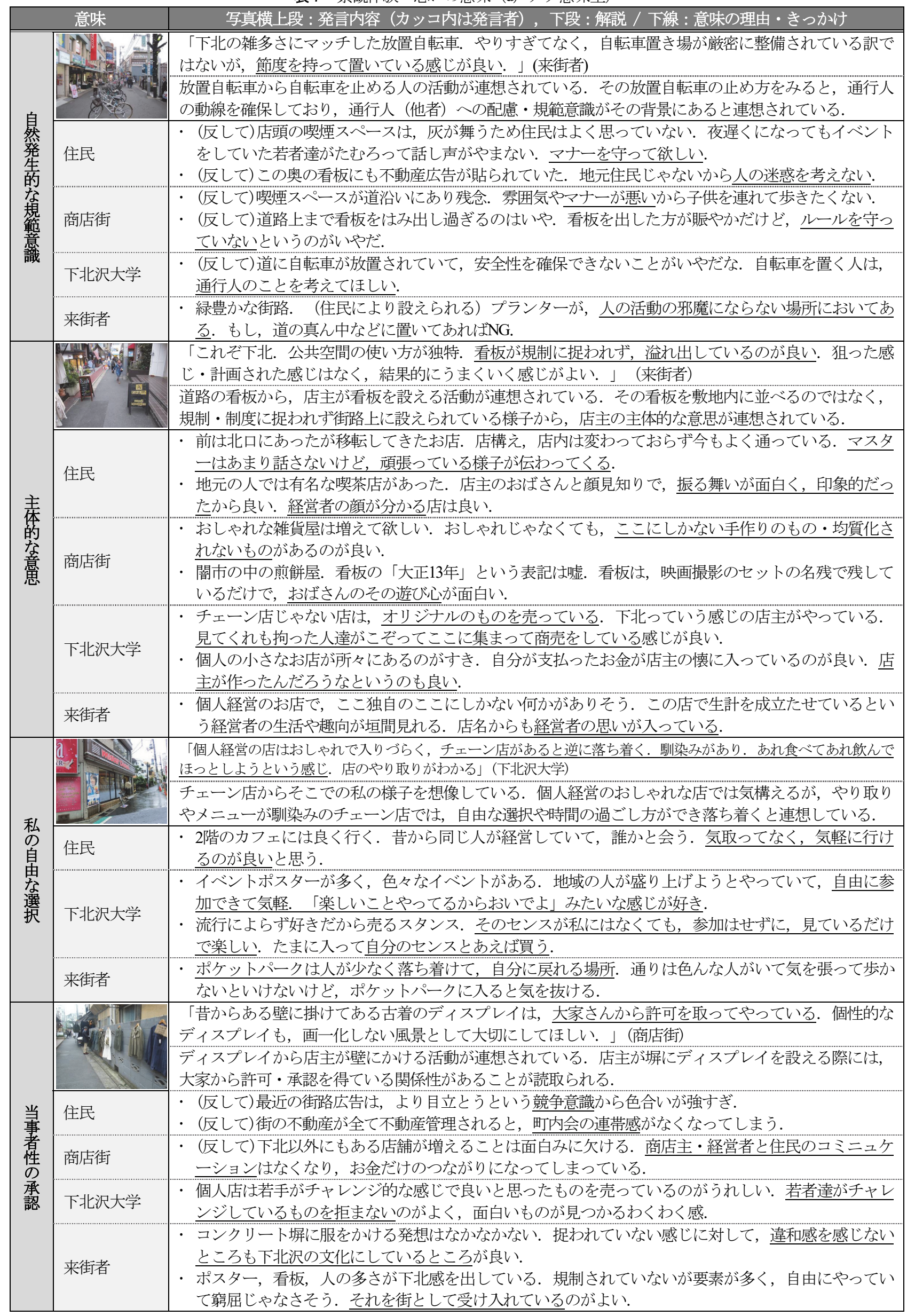


表-8 諸主体が捉える景観体験・思いの意味の比較

\begin{tabular}{|c|c|c|c|c|c|}
\hline 構造 & 景観体験・思いの意味 & 住民 & $\begin{array}{l}\text { 商店 } \\
\text { 街 }\end{array}$ & $\begin{array}{l}\text { 下北沢 } \\
\text { 大学 }\end{array}$ & $\begin{array}{c}\text { 来街 } \\
\text { 者 }\end{array}$ \\
\hline \multirow{3}{*}{$\begin{array}{l}\text { 印象 } \\
\text { 評価 }\end{array}$} & 空間の非日常性 & O & $\triangle$ & $\mathrm{O}$ & $\mathrm{O}$ \\
\hline & 洗練されていないさま & & & $\triangle$ & O \\
\hline & 公的社交. 私的交歓 & $\triangle$ & $\triangle$ & $\triangle$ & O \\
\hline \multirow{5}{*}{$\begin{array}{l}\text { 知覚 } \\
\text { 認識 }\end{array}$} & 空間の広がり & $\triangle$ & $\triangle$ & $\triangle$ & 0 \\
\hline & 奥への誘い & & $\triangle$ & & $\triangle$ \\
\hline & 安全な棲息空間 & O & ○ & $\triangle$ & O \\
\hline & 自然の気配 & $\triangle$ & $\triangle$ & $\triangle$ & O \\
\hline & 時の気配・新陳代謝 & $\triangle$ & O & O & $\triangle$ \\
\hline \multirow{5}{*}{$\begin{array}{l}\text { 意味 } \\
\text { 付与 }\end{array}$} & 親和的な空間 & 0 & 0 & $\bigcirc$ & $\triangle$ \\
\hline & 共同的な活動 & O & $\mathrm{O}$ & & \\
\hline & 活動の営みの痕跡 & $\bigcirc$ & $\triangle$ & O & $\bigcirc$ \\
\hline & 共同体の拠点 & $\triangle$ & $\bigcirc$ & & \\
\hline & まちの縁側 & & & $\triangle$ & $\mathrm{O}$ \\
\hline \multirow{4}{*}{$\begin{array}{l}\text { メタ } \\
\text { 意味 }\end{array}$} & 自然発生的な規範意識 & $\mathrm{O}$ & O & $\triangle$ & $\triangle$ \\
\hline & 主体的な意志 & $\triangle$ & O & 0 & O \\
\hline & 私の自由な選択 & $\triangle$ & & $\triangle$ & $\triangle$ \\
\hline & 当事者性の承認 & $\bigcirc$ & $\triangle$ & $\mathrm{O}$ & $\triangle$ \\
\hline
\end{tabular}

注 : 各主体で発現した人数が，03名/ $\triangle 1 \sim 2$ 名/(無印) なし

思いの意味には，差異や多様性があるように，その帰属 の感覚（当事者性や承認の実感）が，社会的枠組みを持 った共同体（町内会など） 一の強固な帰属か，場所・地 域社会への緩やかな帰属かは，立場や個人により異なる ことも事実である（xiv. 自然発生的な規範意識に関する 各主体の発言等）。そのような差異や多様性を前提とし ても，i）その場所に当事者として関わりたいという意 志を持っていること，ii）その場所が持つ性質により， 当事者性が相互に承認されていると実感できること, iii）そのような場所との関わりを通じて，何らか帰属の 感覚を求めていることは共通した視点である.

今後，下北沢のような多様な主体の関わりがある都市 （商店街）におけるまちづくりでは，同質性を促す方向 性（予め定まったルールや確固とした規範等）ではなく， 異質性や多様性が内包される方向性が模索されるべきで はないだろうか，そのためには，どのような個人・主体 であれ，上述 i）～iii）の視点を有していることを起点 とすれば，他者との相互理解を促し，主体間の個別性を 乗り越えるきっかけになるのではないかと筆者は考える。

\section{5. まとめ}

\section{(1) 結論}

本研究では, 以下の成果が得られた。

3章では，街歩きおよびWSにより場所・対象物の選好 性を分析した結果，住民と商店街は “まち”を生活空間 と捉え，その空間を豊かに寸る対象を選好し，下北沢大 学と来街者は, 外部の視点から様々な対象を選好した.
このような観点は個人や主体の属性に影響されるため, 相互理解を得づらいのではないかと示唆された.

4章では，WSによりa）印象評価型，b）知覚認識型， c）意味付与型，d）メ夕意味型に分類される17の景観体 験・思いの意味が解釈できた．空間の直接的な意味を表 すa）〜c）は空間の接し方により発現する意味が異なる が，d）メタ意味型はほぼ全て発現された。d）メタ意味 型をみると，当事者やその承認により，その場所への帰 属意識を求めている視点は共通しているといえる。 その 事実を相互に前提として，主体間の個別性を丁寧に理解 することが，今後のまちづくりにおける共通認識を形成 していく上での起点になるのではないかと考察された.

\section{(2) 今後の展望}

本研究では，景観体験・思いの意味を通じて，地域社 会に関わる際の意志や作法を前提にすると，共通認識を 形成する上での基盤になるという示唆が得られた．今後, 主体を跨いだ議論等により, 実際に, 共通認識の形成や 歩み寄りの姿勢がみられるか検証することが求められる.

\section{補注}

[1] 後日実施した個別インタビューでは，解釈した景観 体験・思いの意味を被験者に確認した。なお，下北沢 大学1名は協力が得られなかったため, 計11名で害施した。

[2] 本研究は少人数の自由な会話を深く掘り下げる研究方法 やその意義の都合上，被験者が少人数となったが，得ら れた結果を可能な限り，詳細に分析することを重視した。

[3] 2015年4月26日，住民（町内会）を対象としたWSにおける， 2丁目協和会副理事長Tさんの発言.

[4] 世田谷の町会・自治会記載の該当区分を参考にした。 世田谷区町会連合会ホームページ：町会・自治体一

覽<http://www.setagaya-chousourn.org/> (accessed : 2016年12月31日）

[5] 下北沢駅北口・南口あわせて 210 事業所，年間商品販 売額は23,839百万円。（参考文献10)

[6] 2011年12月 28日から2012年1月4日にかけての現地調 查およびヒアリング調査により把握した。

[7] 下北沢大学: 下北沢大学について<http:// shimokitauniv.com/univ/index.htm〉 (accessed : 2016年12月9日)

[8] 2016年5月18日実施のシンポジウム「SHIMOKITAZAWA MEETS PORTLAND一下北沢はポートランドを越えられる か」における，しもきた商店街理事長K氏の発言.

[9] 2011年12月28日，雑貨店店員にヒアリング調查を実施した。 [10] 2015年4月26日，商店街を対象としたWSにおける，しもき た商店街副理事長K氏の発言.

[11] 本来，各主体において性別や年代を偏らない被験者によ る議論が望ましいが，被験者を集める都合上，それぞれ の主体の視点から議論できることを最低限の条件とした。

[12] 来街者は昔を知らないため, 昔好きだった場所は対象外.

[13] 雑誌記事では「ゴッチャリとした街一派手さとにぎ やかさをお互いに競っているような店先や街の看板 たち」など紹介されている（参考文献12，pp.79-94）。 事前に, 被験者に下北沢に関する雑誌を読ませるこ とはせず，日常目にする雑誌記事等より指摘された。 
[14] 青柳瑞穂は，倉敷の職人町の町並みを「何の努力もなし で，その空気の中にやすやすと浸っていたあの通りの， 素朴で, 慎ましさ」と, 生活感が溢れる町並みの魅力を 描写している（参考文献17, pp.204205）。

[15] 中村良夫は「（水辺の料亭では）客のさんざんめきの様 子が，まるで芝居のように対岸からも楽しめた。 そうい う共同体の交歓を風景として市民が共有する習慣」と， 共同体の交歓風景とその風景に自分自身が吸い込ま れる魅力を描写している。（参考文献7, pp.41-42）。

[16] 篠原修は「（居室の内外を）周囲との対比によって，何 か一貫した性質を帯びたものとしてくくり出せる領域」 と自分化された領域を定義する（参考文献18，p.304）

[17] 槇文彦は「農村から都会まで，日本の都市空間の形成の 中で, 求心的な奥性の存在が，その原点にあった」と奥 性の重要性を指摘している（参考文献19，pp.202-204）。

[18] 中村良夫は，「庭でもなく野生の自然でもない，屋敷か らはみ出た，“まちニワ”とでも呼びたい身近な自然が 都市を貫いていた」と都市に散在する自然とその気配の 重要性を指摘している（参考文献17, p.257）。

[19] 中村良夫は, 青柳瑞穂の倉敷の町並みの描写を引用して, 「時代の風とともにゆっくり老いていく町，肩のこらな い健康的な生活感のある町並夕」と，町の生業や活動が 蓄積寸る魅力を指摘している（参考文献17，pp.204206）

[20] 青柳瑞穂は, 倉敷の職人町の町並みを「これらの家々に は人が住んでいて，それぞれ生業を営んでいる。（中 略）やはり底には，古い，伝統的な血液がまだ十分に鼓 動している」と人々の生業や活動の痕跡が連想される風 景の美しさを描写している（参考文献17, pp.204-206）。

[21］[15]の発現場所を「人が居場所として自然に身を寄せる 場」を“寄る辺”と定義した（参考文献7，pp.41-42）。

[22] 中村良夫は「軒先に一輪の牡丹を差し出すことによって, この家の主は，公共的なコミュニティの場へ向けて挨拶 をした」と説明しており, 公共空間やコミュニティに働 きかける作法の魅力を指摘した（参考文献7，pp.44-45）。

[23] ギブソンは，「視覚的なイメージだけでなく，そこを使 うように筋肉感覚，触感覚を伴ってみる」と指摘してい る（参考文献16）

\section{参考文献}

1) 世田谷区 : 風景づくりの手引き，世田谷区，2015.

2) 生駒市：生駒らしい景観づくり一生駒市景観形成基 本計画，生駒市都市整備部みどり景観課，2015.

3) 松島洋介, 奥敬一, 深町加津枝, 堀内美緒, 森本幸 裕：琵琶湖西岸の里山地域における地元住民と移入 住民の景観認識の比較, ランドスケープ研究, Vol. 71, 2008.

4) 岡本卓也, 石盛真徳, 加藤潤三 : 面接調査の技法と しての写真投影法, 関西学院大学先端社会研究所紀 要, pp. 59-69, 2010.3.

5) Lynch, K. : 都市のイメージ，岩波書占，2007.5.

6) 萩下敬雄, 山田圭二郎, 中村良夫 : 景観認識におけ る意識の連関と生成に関する基礎的研究, 土木計画 学会研究論文集, No. 17, pp. 541-546, 2000.9.

7) 中村良夫ら：風景とローカルガバナンス, 早稲田大 学出版部, pp. 211-216, 2014.6.

8) 日本大学史学研究室 佐々木隆爾調査団: 下北沢商店 街の歴史・現状と課題, こうち書房, p. 16, 2001.

9) 高橋ユリカ, 小林正美 : シモキタらしさの DNA, 株 式会社エクスナレッジ, p. 116, 2015.6.

10) 経済産業省: 平成 26 年商業統計表「立地環境特性別 統計編（小売業）」，第 10 表，2014.

11）前掲 9), pp. 114-164 参照

12) 角川書店 : 東京ウォーカー, pp. 79-94, 2002.5.21.

13）池上嘉彦：記号論への招待, 岩波書店, 1993.

14) Cullen, G. : The Conscious Townscape, 1961.

15) 松本直司, 瀬田忠之：折れ曲がり街路空間の期待感 と物的要因の関係, 日本建築学会計画系論文集, No. 526, pp. 153-158, 1999.

16) 中村良夫：環境の解釈学, 学芸出版, pp. 101-1352, 2003.

17) 中村良夫 : 都市からつくる風景, 藤原書店, 2015.5 .

18) 篠原修：景観用語辞典, 彰国社, 1998.11 .

19) 槇文彦：見えがくれする都市，鹿島出版会，1980.

\title{
MEANINGS AND THOUGHTS OF URBAN EXPERIENCES OF TOWNSCAPE IN THE SHIMOKITAZAWA DISTRICT -FOCUSING ON THE DIFFERENCE BETWEEN ACTORS-
}

\author{
Nagomu NAKAUCHI, Keijiro YAMADA, Toshiyuki TAKAHASHI \\ and Masashi KAWASAKI
}

Landscape formation plans have been a common government-led practice in various municipalities that apply theories of urban planning and design to the regulations and recommendations of the physical environment. On top of that a mindset and proactive engagement is required of the landscape-related actors towards an urbanism or machizukuri that sustains the landscape. As such, it is imperative to have a deeper understanding of the urban experiences as well as the self-conscious and personal meanings attached to the landscape, and incorporate the understanding a difference and a common perception and finding the point of contact that they can share each other. Walking around and workshops were conducted with participants of different sociodemographic characteristics in the study in the Shimokitazawa district, and the focus was on the meanings and thoughts of urban experiences of townscape. Further discussions and analyses led to the identification of a typology of 17 kinds of meanings, which fall under 2 categories: i) meanings whose presence depends on the manner of spatial interaction, ii) any actor have the viewpoints to seek a sense of freedom and membership in common in participating in the society. 